\title{
Some of them came home: the Cayman Turtle Farm headstarting project for the green turtle Chelonia mydas
}

\author{
Catherine D.L. Bell, Joe Parsons, Timothy J. Austin, Annette C. Broderick, Gina Ebanks-Petrie and \\ Brendan J. Godley
}

\begin{abstract}
Headstarting is a management technique employed to enhance recruitment of turtles into diminished or extirpated marine turtle populations. Although there have been numerous projects worldwide, there has been a paucity of detailed investigations into its efficacy. Between 1980 and 2001, 16,422 captive-raised hatchlings and 14,347 yearling green marine turtles Chelonia mydas were released from the Cayman Turtle Farm. Approximately $80 \%$ of all turtles released were subject to some form of tagging, including living tags. A total of 392 tagged animals have been recaptured at intervals of up to 19 years. Of this total, 160 individuals were captured in the Cayman Islands and 232 were recorded from other locations within the wider Caribbean and southeastern USA. There was significant variation in the release-recapture intervals at the three countries with most returns (Cayman, Cuba and Nicaragua). A positive
\end{abstract}

relationship exists between time at large and size at recapture and data suggest growth rates comparable to those of wild green turtles in the region. There have been at least six living tag returns, four involving turtles released as yearlings and two involving turtles released as hatchlings. This demonstrates an age at maturity that may be as short as 15-19 years, depending on stage of release. Results show that some headstarted turtles are moving around the Caribbean, surviving for long periods of time, contributing to the local breeding population, and are possibly displaying shifts in habitat utilization with age similar to those recorded by wild individuals.

Keywords Caribbean, Cayman, Chelonia mydas, green turtle, headstarting.

\section{Introduction}

Conservation strategies involving reintroductions, repatriations or relocations of amphibians and reptiles are increasing worldwide (Dodd, 1991). Most marine turtle species are considered threatened (IUCN, 2004), largely because of persistent overexploitation (Eckert, 1995). In addition to protection of surviving wild turtles and their habitats, a number of management techniques have been employed to enhance recruitment into diminished or extirpated populations. In a large number of projects this includes in situ nest protection or transfer of eggs to hatcheries or artificial incubators with subsequent release of hatchlings. One project attempted egg and

Catherine D.L. Bell ${ }^{\star}$ (Corresponding author), Timothy J. Austin and Gina Ebanks-Petrie Department of Environment, PO Box 486GT, Grand Cayman, Cayman Islands, British West Indies. E-mail cbell@seaturtle.org

Joe Parsons Cayman Islands Turtle Farm Ltd, PO Box 645GT, Grand Cayman, Cayman Islands, British West Indies.

Annette C. Broderick and Brendan J. Godley Marine Turtle Research Group, Centre for Ecology and Conservation, University of Exeter in Cornwall, Trenough Campus, Penryn, TR10 9E2, UK.

*Also at: Marine Turtle Research Group, University of Exeter in Cornwall.

Received 4 December 2003. Revision requested 2 June 2004. Accepted 2 November 2004 hatchling dispersal to a large number of regional locations (Eliazar et al., 1996). However, perhaps the most elaborate technique attempted has been headstarting (Huff, 1989; Fontaine et al., 1990; Wood \& Wood, 1993; Caillouet, 2000), a technique whereby newly hatched turtles are taken into captivity and maintained for a period of time, most often 9-12 months, when they are at a size at which natural mortality factors that affect hatchlings are minimized (Woody, 1990; Donnelly, 1994; Mortimer, 1995). This is thought to increase the likelihood of survival to adulthood, with the aim of subsequently increasing relative levels of recruitment to foraging assemblages and ultimately breeding populations.

Headstarting has been employed for most species of marine turtles (see Donnelly, 1994, and Mrosovsky, in press for reviews). The most prominent efforts have been for Kemp's ridley turtles Lepidochelys kempii at Padre Island National Seashore, Texas (Fontaine et al., 1990; Caillouet et al., 1992, 1993; Klima \& McVey, 1995), and green turtles Chelonia mydas in Florida (Huff, 1989) and the Cayman Islands (Wood \& Wood, 1993). Whereas some headstarting projects have been subject to scrutiny (Eckert et al., 1994) there has been little analysis of the efficacy of most projects (Wibbels et al., 1989; Eckert et al., 
1994), although this has not limited debate about the technique.

The value of this practice as a conservation method has been challenged. Headstarting has been perceived as a 'half-way technology' (Frazer, 1992) that does not address the cause of population declines (Woody, 1990; Mortimer, 1995) but merely seeks to remedy the effects. Critics have suggested that conservation efforts should be concentrated on increasing research into wild populations rather than raising more turtles (Williams, 1993; Byles, 2001), suggesting that headstarting projects are expensive relative to the return (Woody, 1991).

The biological dependability of the technique has been widely debated. Captive reared turtles may behave differently than wild turtles when released into the wild (Bolten et al., 1990). Kemp's ridley turtles have been found in Nicaragua and Morocco, well outside what is thought to be their normal foraging range (Woody, 1991), and nesting attempts in Florida and the Carolinas, USA, outside what is considered their normal nesting range, have led to speculation over whether these turtles may be headstarted animals (Bowen et al., 1994). The ability of headstarted turtles to survive in the wild has also been questioned, with putative causes of failure to thrive being nutritional deficiencies and behavioural modifications resulting from factors associated with captivity, such as insufficient exercise, lack of, or inappropriate stimuli, and unavailability of natural food or feeding techniques (National Research Council, 1990; Woody, 1990; Eckert et al., 1994).

There have been two concerns about the possible impact of headstarting on existing wild populations. Firstly, the possible release of asymptomatic, infected turtles raised in intensive conditions and released into wild populations could have the potential for deleterious effects (Woody, 1981; Dodd, 1991; Jacobson, 1993, 1996; Donnelly, 1994). Secondly, concern has been expressed over the release of animals genetically alien to their environment (Mrosovsky, 1983; Karl et al., 1995), with reference to alteration of genetically specific natural behaviours in turtles (Karl et al., 1995) and outbreeding, which may cause a decrease in biological fitness in other species (Rhymer \& Simberloff, 1996). Furthermore, before incubation procedures were subject to temperature monitoring and control, it is possible that headstarting projects that involved the in vitro incubation of eggs may have resulted in unintentionally skewed sex ratios (Woody, 1991; Mrosovsky, in press). Finally, it has been suggested that as many headstarting projects are experimental, they lack a framework within which their success can be measured, and therefore the hypothesis testing, monitoring and evaluation involved are not scientifically valid (Woody, 1991; Eckert et al., 1994; Heppell \& Crowder, 1998).
Here we describe the results of a 22-year headstarting programme in the Cayman Islands run by Cayman Turtle Farm Ltd. This release programme was carried out to determine whether headstarted turtles were capable of surviving in the wild and recruiting to breeding populations. It was also hoped that data could be provided concerning age at sexual maturity, and that returns would provide geographical insights into migration and the selection of nesting and foraging grounds (J. Wood, pers. comm.).

\section{Methods}

\section{The Cayman Turtle Farm}

The Cayman Turtle Farm has been in operation since 1968 as a commercial venture to raise green turtles. To form the herd, eggs, adults and subadult turtles were collected from the wild. A minimum of 477,644 eggs were collected from Ascension Island, Costa Rica, Guyana, and Suriname between 1968 and 1978. Additionally, 60 adults were collected from Ascension Island, Costa Rica, Guyana, and Suriname, over 1968-1973, an additional 117 adults and subadults were obtained from Mexico over 1976-1977, and 31 individuals of adult size (24 females and 7 males) were purchased from Caymanian vessels fishing the Mosquito Keys of Nicaragua over 1970-1971 (Cayman Turtle Farm, 2000).

Adults are held in a large breeding pond $\left(2,953 \mathrm{~m}^{3}\right)$ with an artificial nesting beach. Eggs from each clutch laid on the beach are incubated in a hatchery (Wood \& Wood, 1979; Critchley et al., 1983) and then hatchlings are reared in groups. Animals selected for release are in excess of what is required for local utilization and future breeding stock and has, in the past, been 10-15\% of annual production (Cayman Turtle Farm, 2000). The stock level has varied over the years. By 2001 the breeding herd was 355 (94 males, 261 females) and mean annual production of hatchlings over 1980-2001 was 10,500. In November 2001 Hurricane Michelle caused severe damage to the Farm and $78 \%$ of the breeding stock was washed out to sea. Since then a new breeding facility has been built further from the sea. The Cayman Turtle Farm continues to provide meat at reduced levels for local consumption and remains one of the major tourist attractions on Grand Cayman.

\section{Headstarting releases}

Between 1980 and 2001 a total of 30,769 animals were released, including 16,422 neonates, 14,282 yearling turtles from the previous nesting season (typically 11-15 months old) and 65 older turtles of 19-77 months old. The mean size and weight of yearling turtles was $29 \mathrm{~cm}$ straight carapace length (SCL) and $3.0 \mathrm{~kg}$ (Wood 
\& Wood, 1985, 1993; Bjorndal et al., 2003). Criteria for selection included being of typical size and weight and apparent good health. No animals exhibiting clinical signs of disease were included in the release programme.

Releases typically took place in October or November. There was no fixed site for release, although most frequently sites on Seven Mile Beach, western Grand Cayman, or within the North Sound of the island were used, the latter chosen for its abundance of sea grass, sponges and algae, and the protection and shelter afforded by the proximity of the fringing reef in this area. Releases were public events, with the aim of increasing awareness and educating the public as to the status of the green turtle and the Farm's role in conservation.

\section{Tagging}

A diversity of tagging methods was used to mark turtles. These are described in detail in Wood (1991). Between 1980 and 1981, 1,268 yearling turtles were subject to notching, in which the trailing marginal scutes were notched to identify the release group (Wood, 1982). Between 1981 and 1994 combinations of flipper tags, individually numbered titanium tags bearing a return address applied to the trailing edge of the left front flipper, and living tags created by the transplantation of a $4 \mathrm{~mm}$ diameter disc of plastron to the carapace were used for identification (Hendrickson \& Hendrickson, 1981; Wood \& Wood, 1993). Additionally, between 1981 and 2001, a further 6,022 unmarked animals (2,243 hatchlings and 3,779 older turtles) were released (Table 1 ).

\section{Recapture data}

Foreign recapture data are based on tag returns from directed and incidental capture in fisheries throughout the wider Caribbean and stranding networks in the USA. Not all records had complete spatial and temporal data. In cases where recapture data were incomplete and only the month of recapture was given, date of recapture was assumed to be the first day of the month, and in cases where only the year is known, date of recapture was assumed to be 1 January, thus giving a 'minimum time at large'. Records of tag numbers that could not be confirmed as Cayman Turtle Farm tags were discarded. Tag returns were largely recorded between 1984 and 2001, although records of 3 or possibly 4 reproductively active animals were recorded more recently. All living tag returns except one were documented photographically. As they were all made after $\geq 15$ years at large

Table 1 Number of hatchlings and yearlings released in each year and type of tagging method used. For the purposes of these data numbers of older turtles are so few that they are included as 'yearlings', i.e. non-hatchlings.

\begin{tabular}{|c|c|c|c|c|c|c|c|c|c|c|c|}
\hline \multirow[b]{2}{*}{ Year } & \multirow{2}{*}{$\begin{array}{l}\text { Notching } \\
\text { Yearling }\end{array}$} & \multirow{2}{*}{$\begin{array}{l}\text { Flipper tag } \\
\text { Yearling }\end{array}$} & \multirow{2}{*}{$\begin{array}{l}\text { Living tag } \\
\text { Hatchling }\end{array}$} & \multirow{2}{*}{$\begin{array}{l}\text { Living \& } \\
\text { flipper tag }\end{array}$} & \multirow{2}{*}{$\begin{array}{l}\text { No tag } \\
\text { Hatchling }\end{array}$} & \multicolumn{3}{|c|}{ Totals } & \multicolumn{3}{|c|}{ Recaptures } \\
\hline & & & & & & Yearling & Hatchling & Yearling & Both & $\begin{array}{l}\text { Cayman } \\
\text { Islands }\end{array}$ & Elsewhere \\
\hline 1980 & 1,208 & & & & & & & 1,208 & 1,208 & 2 & \\
\hline 1981 & 60 & 1,331 & 79 & & & 294 & 79 & 1,685 & 1,764 & 1 & \\
\hline 1982 & & & & & & & & & & & \\
\hline 1983 & & & $4,405^{*}$ & & & 71 & 4,405 & 71 & 4,476 & 1 & \\
\hline 1984 & & 977 & & $1,023^{*}$ & & & & 2,000 & 2,000 & 60 & 55 \\
\hline 1985 & & & $2,641^{*}$ & & 466 & & 3,107 & & 3,107 & 3 & \\
\hline 1986 & & 998 & & 938 & & & & 1,936 & 1,936 & 42 & 66 \\
\hline 1987 & & & 5,082 & 500 & 477 & & 5,559 & 500 & 6,059 & 7 & 10 \\
\hline 1988 & & & & $1,202^{*}$ & & & & 1,202 & 1,202 & 29 & 68 \\
\hline 1989 & & 119 & 1,500 & & 1,300 & 1,650 & 2,800 & 1,769 & 4,569 & 2 & 1 \\
\hline 1990 & & & & 104 & & & & 104 & 104 & 1 & 3 \\
\hline 1991 & & 98 & 472 & & & & 472 & 98 & 570 & 1 & 1 \\
\hline 1992 & & & & & & & & & & 2 & 2 \\
\hline 1993 & & 2 & & 602 & & & & 604 & 604 & 8 & 7 \\
\hline 1994 & & & & 129 & & & & 129 & 129 & & 3 \\
\hline 1995 & & 102 & & & & & & 102 & 102 & & 2 \\
\hline 1996 & & 100 & & & & & & 100 & 100 & & 2 \\
\hline 1997 & & & & & & 440 & & 440 & 440 & & \\
\hline 1998 & & 4 & & & & 400 & & 404 & 404 & & \\
\hline 1999 & & 9 & & & & 828 & & 837 & 837 & & 1 \\
\hline 2000 & & 542 & & & & 96 & & 638 & 638 & & \\
\hline 2001 & & 520 & & & & & & 520 & 520 & 1 & \\
\hline Total & 1,268 & 4,802 & 14,179 & 4,498 & 2,243 & 3,779 & 16,422 & 14,347 & 30,769 & 160 & 221 \\
\hline
\end{tabular}

*Numbers in bold represent groups of turtles that have resulted in adult, living tag returns. 
and could be therefore be considered adults, these animals are considered separately in the results.

Local recapture information was largely part of an active recapture effort prior to 1994 (Wood \& Wood, 1993), and recapture information after this time has come from dead or injured animals, fishermen's reports, and observations of nesting females. During active recapture sessions in Cayman, nets were set along mangrove fringes within the sounds and once captured, missing or deteriorating flipper tags were removed and replaced as necessary. Where animals were recaptured more than once, only the most recent capture was included in analyses. Where records were inconsistent, data were discarded. All locally recaptured animals included in size analyses were released as yearlings.

Distance between release and recapture location was determined using ArcGIS (ESRI, Redlands, USA) and Garmin (Olathe, USA) Global Positioning System software. These generate a minimum straight line swimming distance between two locations. Where the location within a country was not known, the minimum distance from Grand Cayman to that country was calculated. For travel from Cayman to Florida, USA, and the northern coast of Cuba, the mean distance of routes around both the Eastern and Western tip of Cuba were used.
Growth data were calculated by converting known curved carapace length (CCL) measurements into SCL using a conversion factor (Wood \& Wood, 1993). Mean size at release $(29 \mathrm{~cm} \mathrm{SCL})$ was subtracted from reported size at recapture to give an indication of growth during time-at-large. Foreign recapture morphometric data were not included, as methods of measurement could not be verified. Growth data generated from recaptures of animals that had spent $<1$ year at large were discarded to minimize errors in growth rate estimation. Similar filtering techniques have been used by Chaloupka \& Musick (1997), Bjorndal et al. (2000), Bresette \& Gorham (2001), and Diez \& Van Dam (2002).

\section{Results}

\section{Spatial pattern of recaptures}

Recapture data $(n=392)$ show that turtles have dispersed throughout the wider Caribbean (Fig.1). A total of 160 turtles were recovered in the Cayman Islands, including individuals identified from flipper tags $(n=154)$ and living tags $(n=6)$. All animals recovered outside Caymanian waters were initially identified from flipper tags $(n=232)$; two from Belize, 176 from Cuba, eight from Honduras, one from Mexico, 38 from

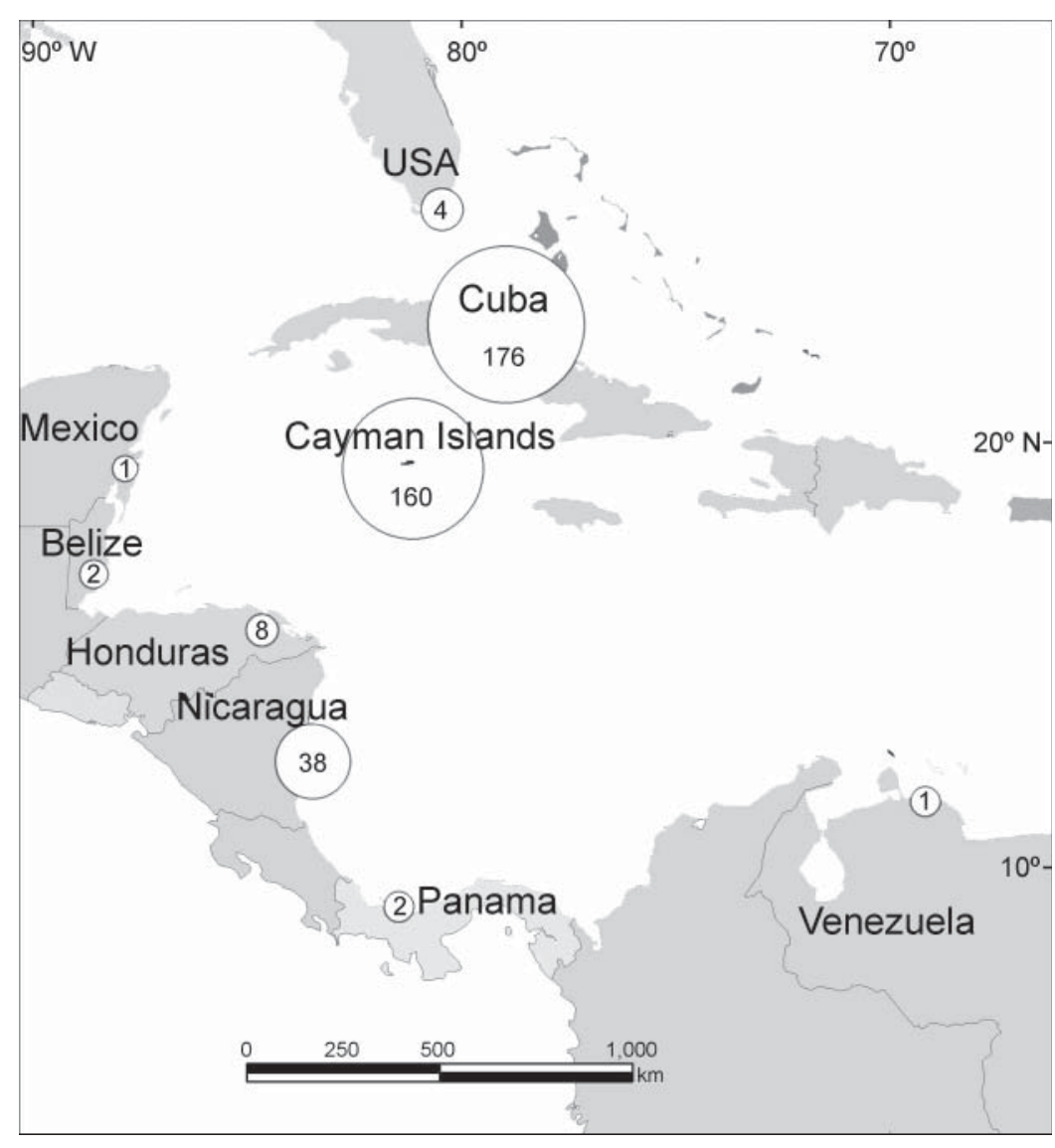

Fig. 1 Map of the wider Caribbean region showing location and frequency of recaptures of headstarted turtles. 

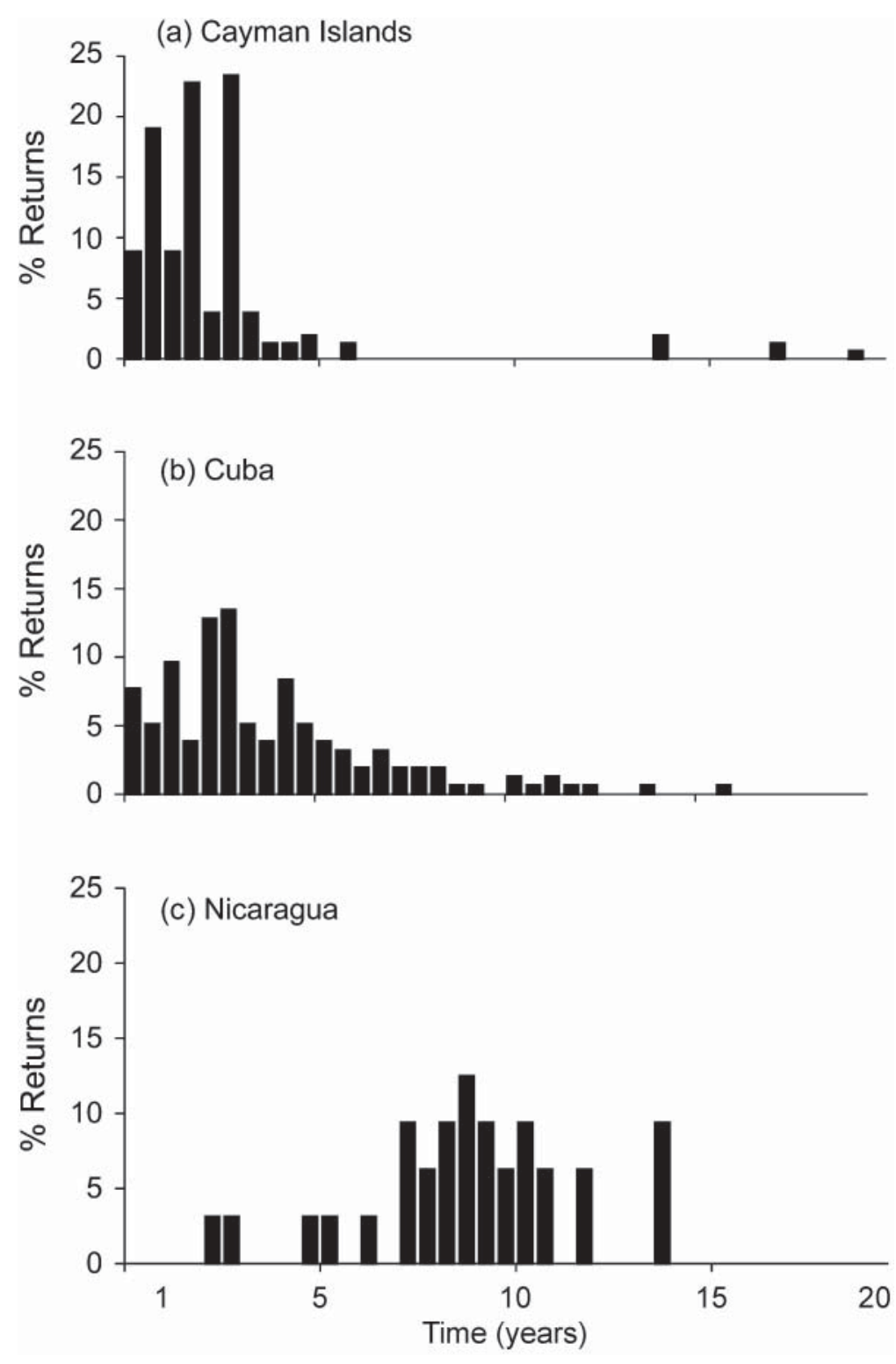

Fig. 2 The percentage of turtles recaptured in each 6 month interval following release of those recaptured in the waters of (a) the Cayman Islands, (b) Cuba and (c) Nicaragua over 1980-2002. Median \pm SD (range): Cayman Islands $22 \pm 34$ months (1-226 months), $\mathrm{n}=158$; Cuba $34 \pm 35$ months (1-187 months), $\mathrm{n}=156$; Nicaragua $108 \pm 33$ months (27-167 months), $\mathrm{n}=32$.
Nicaragua, two from Panama, four from USA and one from Venezuela.

There have been 29 multiple recaptures of individuals. Of these 19 animals were recaptured more than once within Cayman waters, six were captured more than once within Cuban waters, one was captured twice in Belize, one was caught in Cayman 2 years after release and again in Cuba 1 year later, one was captured in Cuba 1.5 years after release and back in Cayman 2 years later, and one was captured in Cayman 3 years after release and 4 years later in Honduras.

The overall percentage of flipper tagged turtles that were recaptured was $4.2 \%$ (2.5\% foreign, $1.7 \%$ local; 392 of 9,300 individuals); this varied from year to year. There was a significant correlation between the number of flipper-tagged yearlings released in each cohort and the number of that cohort recaptured locally only (Table 1; Spearman's Rank Correlation: releases vs local recaptures $\mathrm{R}_{\mathrm{s}}=0.58, \mathrm{P}<0.005$; releases vs foreign recaptures $\left.R_{s}=0.16, P>0.05\right)$.

\section{Temporal pattern of recaptures of individuals}

There was a significant difference in median recapture intervals for animals from the three countries of most recaptures (Kruskall-Wallis $\mathrm{H}_{2}=89.9$, $\mathrm{P}<0.001$, Cayman $>$ Cuba $>$ Nicaragua; Fig. 2). A nonparametric post-hoc multiple comparison test for unequal samples revealed the greatest difference to be between Cayman and Nicaragua, followed by Cuba and Nicaragua, and lastly between Cayman and Cuba. Recaptures from Belize $(n=2)$ occurred after 72 and 78 months, 
Honduras $(n=7) 1,1,3,4,17,82$ and 94 months, Mexico $(n=1) 2$ months, Panama $(n=2) 37$ and 78 months, United States $(n=3) 3,4$, and 168 months and Venezuela $(n=1) 9$ months. In 12 cases flipper tagged yearlings were recaptured after periods short enough ( $<160$ days) to gain meaningful insight into minimum speed of travel capabilities, with a mean \pm SD (range) of $10.2 \pm 8.1$ $\left(4.1-31.1 \mathrm{~km} \mathrm{day}^{-1}\right)$.

\section{Living tag returns}

There have been 7 adult living tag returns, 6 local and 1 from Florida, USA. (Table 2). The foreign return was primarily identified by a flipper tag, following which communication was made with Cayman Turtle Farm who assisted in the identification of the living tag. As a result of photographic documentation and individual circumstances there is no doubt that individuals A-F are different. However, it is not certain whether individuals $\mathrm{E}$ and $\mathrm{G}$ are two different females, despite being observed at different localities at an interval of 28 days, as one of the tags was not photographically documented. All recaptured living-tagged animals were either sexually dimorphic or reproductively active at the time of capture. Four of the seven individuals with living tags were released as yearlings and reached maturity after c. 15 years both in males $(n=3)$ and the single female. The recapture interval of the individuals released as hatchlings provide point estimates of time to maturity of 19 and 17 years for the male and female(s), respectively. All observations of female living-tagged turtles were made on Seven Mile Beach, Grand Cayman. Of those recaptures recorded nesting, hatch data were recorded for two of the three individuals, animals $E$ and $G$, clutch size, $112(\mathrm{E}), 110(\mathrm{G})$; hatch success, 63\% (E), 88\% (G); fertilization success, $71 \%(\mathrm{E}), 90 \%$ (G); incubation period, 54 days $(\mathrm{E}), 65$ days $(\mathrm{G})$.

\section{Contribution to local wild reproductive populations}

Over 1999-2003 the mean annual number of green turtle nests recorded on Grand Cayman has been 16.4.
(Cayman Islands Department of Environment, unpubl. data). Based on intra-annual green turtle re-nesting frequencies of 2-5 clutches per year, we calculate a mean annual reproductive population of 2-8 green turtles in Grand Cayman each year. Nocturnal observations were made only in 2002 and 2003. During this time 8 green turtles have been observed nesting, (2002 $n=6,2003$ $n=2$ ). At least 2 of these were confirmed as Farm released animals.

\section{Morphometrics and growth rates}

Size of turtles recaptured in Cayman waters were $32.5-104.0 \mathrm{~cm}$ SCL $(n=114)$; the most frequent size class recaptured was $41-50 \mathrm{~cm}(n=69)$ (Fig. 3a). There was a positive correlation between time at large and size at recapture (Fig. $3 b ; r^{2}=0.85, F_{1,113}=618, \mathrm{P}<0.001$ ). Mean growth rates since release were $2.2-13.6 \mathrm{~cm} \mathrm{yr}^{-1} \mathrm{SCL}$ with the majority of animals ( $80 \%$ ) having mean absolute growth rates of $4.0-8.9 \mathrm{~cm} \mathrm{yr}^{-1}$ SCL (Figure 3c). When mean growth rates (Fig. $3 \mathrm{~d}$ ) are compared it can be seen that this suggests non-monotonic growth rates, with a peak of $8.5 \mathrm{~cm} \mathrm{yr}^{-1}$ in animals captured at sizes of $51-60 \mathrm{~cm}$, and lower in animals recaptured in both smaller and larger size classes.

\section{Discussion}

Headstarted green turtles can survive and can reach adulthood and appear, at least in part, to be able to return to their release site to breed. Thus, regardless of some of the criticisms of the technique, it may be possible to reseed extinct or severely diminished populations such as that of the Cayman Islands (Aiken et al., 2001) through the release of headstarted individuals. The green turtle nesting population in the Cayman Islands is extremely small. Of eight individuals observed nesting over 2 years, at least $25 \%$ of these have been headstarted individuals.

There are, however, limitations to all tagging methods that reduce the potential for detection of success. While flipper tags are widely recognizable, they are not

Table 2 Data for all recaptured living-tagged turtles.

\begin{tabular}{|c|c|c|c|c|c|c|c|c|}
\hline Individual & Release year & Recapture date & $\begin{array}{l}\text { Capture } \\
\text { location }\end{array}$ & Status & $\begin{array}{l}\text { Curved carapace } \\
\text { length }(\mathrm{cm})\end{array}$ & Age at release & $\begin{array}{l}\text { Age at recapture } \\
\text { (years) }\end{array}$ & Sex \\
\hline A & 1984 & 27 Apr. 1998 & Grand Cayman & dead & 97 & yearling & 15 & M \\
\hline B & 1984 & 24 May 1998 & Grand Cayman & alive, injured & 95 & yearling & 15 & $\mathrm{M}$ \\
\hline C & 1984 & 1 Oct. 1998 & Florida, USA & alive & 93 & yearling & 15 & M \\
\hline $\mathrm{D}$ & 1983 & 13 July 2002 & Grand Cayman & mating & 108 & hatchling & 19 & $\mathrm{M}$ \\
\hline$E^{*}$ & 1985 & 17 Aug. 2002 & Grand Cayman & nesting & - & hatchling & 17 & $\mathrm{~F}$ \\
\hline $\mathrm{F}$ & 1988 & 25 Aug. 2002 & Grand Cayman & nesting & 108 & yearling & 15 & $\mathrm{~F}$ \\
\hline G & 1985 & 14 Sep. 2002 & Grand Cayman & nesting & - & hatchling & 17 & $\mathrm{~F}$ \\
\hline
\end{tabular}

*This tag was not documented by a photograph, and it is possible that this could be the same individual as turtle G. 

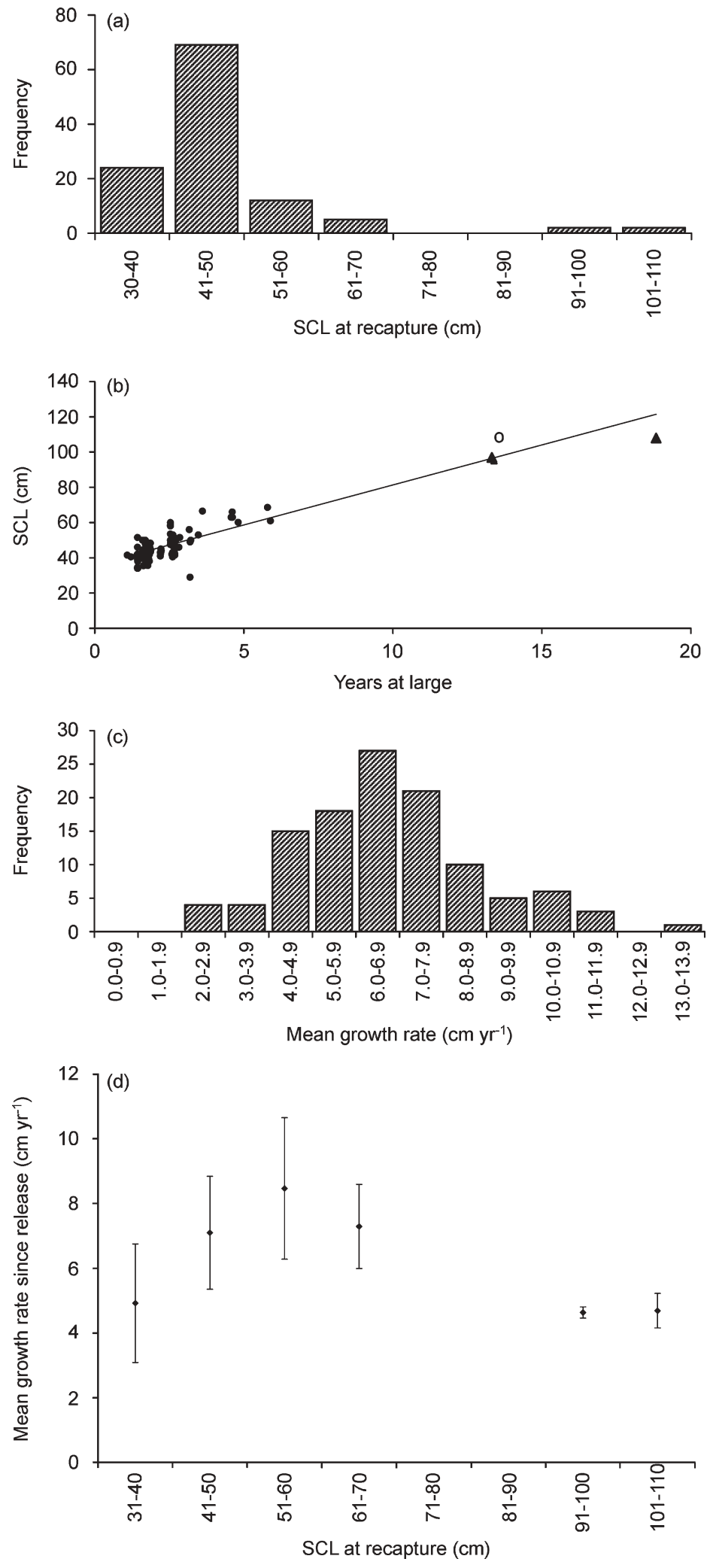

Fig. 3 Growth data for Cayman Island recaptures only $(\mathrm{n}=114)$. (a) Frequency histogram of size (straight carapace length, $\mathrm{SCL}$ ) of turtles recaptured in the Cayman Islands. (b) SCL at recapture $(\mathrm{cm})$ versus time at large (years) for turtles at large for $>1$ year; factor used to convert curved carapace length to SCL was 0.96 , based on Wood \& Wood (1993); $\bullet=$ immature animals, $\mathrm{O}=$ known adult female size, $\boldsymbol{\Delta}=$ known adult male size. SCL $(\mathrm{cm})=0.36 *$ time at large (months) +34.4$)$; a higher order model did not explain significantly more variance than the simple linear regression. (c) Frequency of mean growth rate (SCL, $\mathrm{cm} \mathrm{yr}^{-1}$ ) in recaptured animals. (d) Mean \pm SD growth rate since release $\left(\mathrm{SCL}, \mathrm{cm} \mathrm{yr}^{-1}\right)$ in recaptured animals in $10 \mathrm{~cm}$ classes of size at recapture. applicable to hatchlings, tag loss rates are high, and internalization of tags (where the flipper grows over the tag making it undetectable from the outside) can also occur. Four of the adult sized headstarted turtles identified by living tags were released with flipper tags also. Only one of the four was recaptured bearing a 
flipper tag. Living tags may overcome some tag loss issues, but tag loss from this procedure has also been recorded (Wood \& Wood, 1993). Living tags are not widely recognized outside the country of origin, are largely non-returnable, and in this project limit identification to age and year of release. Additionally, as there has been more than one organization using the system without standardization, there is the potential for confusion (Bjorndal et al., 2003).

\section{Recruitment and growth rates of headstarted turtles}

Growth in locally recaptured headstarted green turtles appears to be non-monotonic. A peak in integrated growth rates was recorded for turtles recaptured at 51-60 cm SCL and is in concordance with what would be expected if growth rates were comparable to size specific growth rates of wild green turtles in Great Inagua, Bahamas (Bjorndal \& Bolten, 1988), Mosquito Lagoon, Florida (Mendonca, 1981), US Virgin Islands (Boulon \& Frazer, 1990), Culebra, Puerto Rico (Collazo et al., 1992), and Hutchison Island, Florida (Bresette \& Gorham, 2001).

The return of released living-tagged turtles indicated an age at maturity of 15-19 years, although these individuals could conceivably have matured earlier and there may be other individuals of the same cohorts yet to mature. However, these limited data place age at maturity towards the lower range of that previously estimated for green turtles in the wild. (Frazer \& Ehrhart, 1985; Zug \& Glor, 1998; Mrosovsky \& Godfrey, 2003). It has been suggested that there is a marked condensed maturation time because of the headstarting of animals past the pelagic phase, subsequently speeding up the growth process (Mrosovsky \& Godfrey, 2003). However, the return of animals released as hatchlings at comparable ages to those released as yearlings suggests that this is not the case. The pelagic phase in wild animals may be even shorter than the 3-5 years suggested by Zug \& Klor (1998). It may also be that while yearling turtles adjust to life in the wild there is a slowing of growth that partially negates the head start they have received. Wood \& Wood (1993) observed an initial decrease in weight gain from an average projected $6.6 \mathrm{~kg} \mathrm{yr}^{-1}$ in captivity to $3.0 \mathrm{~kg} \mathrm{yr}^{-1}$ in the wild, within the size range sampled.

\section{Movements within the wider Caribbean}

Captures of headstarted animals were not evenly distributed around the region, with clusters in Cuba and Nicaragua, both of which have active turtle fisheries. Cuba has a well monitored turtle fishery, leading to increased likelihood of reported captures (Gavilan, 2000), but it seems likely that there may also be an oceanographic influence. The clockwise circulation to the north-west of Cayman (Fig. 4), known as the Cuban Vortex, is set up by the Loop Current flowing directly toward the Florida Current and causing a shear in the flow to create this quasi-permanent recirculation (Coats, 1992). As small turtles leave the Cayman Islands it is likely that their movements will be strongly influenced by these currents (Carr, 1987), and this may explain the timing and number of captures from Cuba.

However, given that spatial shifts occur in all species of marine turtles, and in green turtles there is a known migration between spatially separate pelagic, developmental, adult foraging and breeding ground habitats (Meylan, 1995; Bolten, 2002) it is probable that as headstarted individuals mature they actively migrate to other locations. In this case, migration to Nicaraguan waters as large juveniles and adults is plausible. Nicaragua's coastal shelf supports extensive pastures of the seagrass Thalassia testudinum, on which large numbers of adult and subadult green turtles forage (Meylan, 1995). The feeding assemblage there is also subject to a significant harvest (Lagueux, 1998). The variation in the recapture intervals in Cayman, Cuba and Nicaragua support this sugestion. It appears turtles are generally leaving Cayman waters over the first few months or years and moving, perhaps relatively passively, to other waters such as those of Cuba and then making further age related (presumably size specific) shifts to other areas such as the waters of Nicaragua. This assumption is, however, based on the lack of recaptures in Cayman waters between 6 and 14 years at large, and cessation of active recapture efforts in Cayman after 1994 may have influenced these results.

While the vast majority (94\%) of foreign recaptures were after periods so long ( $>100$ days at large) as to negate the utility of drawing inferences regarding speed of movement, some individuals were recaptured in foreign waters after comparatively short durations. The high speed of displacement of these individuals indicates some degree of directed travel, suggesting dispersal may not be entirely dependent on prevailing currents. One turtle reached Honduras after 24 days, travelling at minimum speeds of $27 \mathrm{~km} \mathrm{day}^{-1}$ (Wood \& Wood, 1993) and another to Honduras in 18 days $\left(31 \mathrm{~km} \mathrm{day}^{-1}\right)$. Minimum speeds of travel inferred for adult wild turtles tagged in the Caribbean reported by Meylan (1995) were $23-66 \mathrm{~km} \mathrm{day}^{-1}$. Satellite telemetry of migrating individuals has shown that adult and juvenile green turtles are capable of reaching and maintaining these speeds of travel for considerable periods of time (Godley et al., 2003).

\section{Disease transfer and genetic pollution}

Two criticisms of headstarting that cannot be addressed by our data are those of potential disease transfer and 


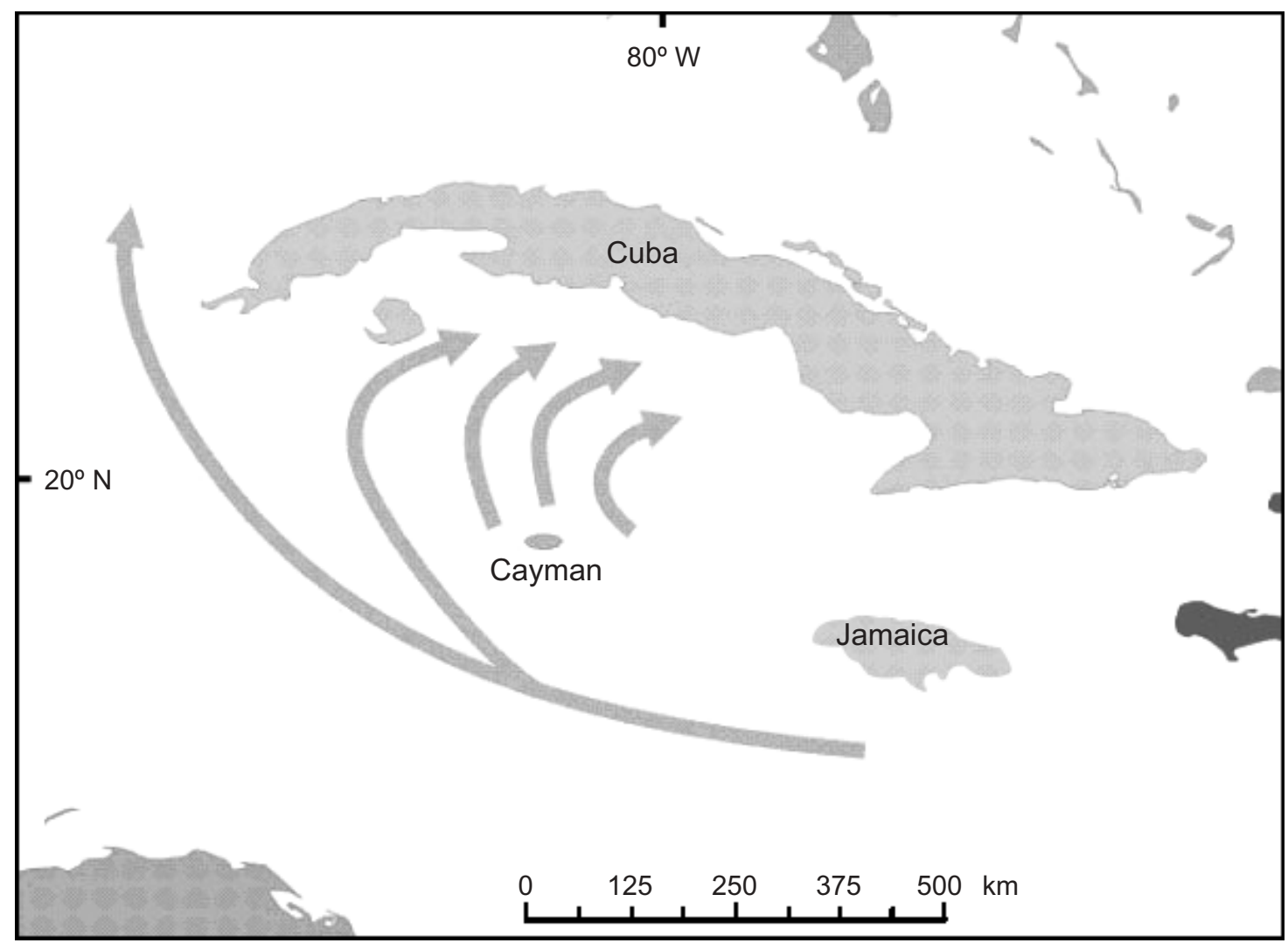

Fig. 4 Map of the wider Caribbean showing Caribbean current and Cuban vortex during October-December. Adapted from ocean current map available at HYCOM Consortium (2004).

genetic pollution. Releasing captive reared animals into the wild will always carry the risk of inadvertent introduction of disease and parasites. However, precautions are taken at the Cayman Turtle Farm to ensure this risk is kept to an absolute minimum.

With respect to genetic pollution, i.e. loss of genetic specification of wild turtle stocks caused by introduced individuals, the majority of the Farm stock was founded from eggs and adults of Caribbean origin. The only turtles brought from outside the wider Caribbean were those from Ascension Island $(17.7 \%$ of the total number of eggs collected and $3.3 \%$ of subadult and adults). Turtles originating from Ascension Island may also migrate to within the wider Caribbean (Lahanas et al., 1998; Luke et al., 2004). Moreover, although introduction of novel genetic material is usually viewed as negative, Krueger \& May (1991) noted that a small amount of gene transfer $(<0.1 \%)$ could increase the capability for adaptation because of the introduction of genetic variations. Increased genetic variability can counteract bottleneck effects associated with loss of genetic variability in small breeding populations (Dutton et al., 1999). Molecular analysis of the Cayman Turtle Farm stock, currently underway, may shed further light on the precise origins of headstarted animals.

\section{Evaluating the project}

Several authors have described criteria for a successful headstarting project (Eckert et al., 1994; Mortimer, 1995; Caillouet, 1998; Balazs et al., in press). If headstarted turtles must be proven to join wild populations, locate nesting beaches at or in proximity to those of their release, mate successfully and produce viable offspring (Eckert et al., 1994; Caillouet, 1998) then the return of the known headstarted turtles, despite the small number, may be considered an indication of success for the Cayman Turtle Farm experiment, as it has in other projects (Shaver \& Caillouet, 1998). However, the high cost of headstarting must be considered, and was in this case subsidized by the ancillary project of livestock production, and to some extent offset by its contribution to local education and community enrichment. Headstarted turtles were often those surplus to production. The high cost, and the potential for disease transfer and genetic pollution, should be considered if this model were to be applied in other areas solely as a method of restocking or reseeding extinct or extirpated populations.

The Cayman Islands have a long history of commercial exploitation of the green turtle. Local stocks were 
thought to have been extirpated by 1900 (Lewis, 1940; King, 1995) but green turtles continue to nest at extremely low levels (Aiken et al., 2001; Bell \& Austin, 2002). It is not known what proportion of these turtles are a remnant of the former rookery, immigrants from adjacent rookeries in the Western Atlantic or headstarted turtles from the Cayman Turtle Farm (Wood \& Wood, 1993). Our limited data suggest that headstarted individuals may form a significant proportion of the nesting population.

In conclusion, there are several aspects of headstarting that can now be qualified as a result of our data. Headstarted turtles are moving around the Caribbean, surviving for long periods of time, and possibly displaying size specific age-related shifts in habitat utilization in the same way as wild turtles. Some individuals are known to have reached adulthood and returned to breed. These numbers may be higher than reported here as the limitations of tagging methods and monitoring make it possible that nesting occurring both in Cayman and elsewhere is not being reported. Turtles have been released without tags, flipper tag loss rates are high, and in many cases tags may be internalized rather than lost, as individuals survive for extended periods of time. Living tags may be ignored or mistaken for natural markings. Current molecular analysis of the nesting green turtles of the Cayman Islands may shed additional light on the origins of the individuals in the remaining rookery.

\section{Acknowledgements}

This study was facilitated by the involvement of many individuals and organizations during its 22 year lifespan within the Cayman Turtle Farm and abroad. We would particularly like to thank all those who assisted in returning tags, including Cynthia Lagueux, Felix Moncada, individuals at Florida Marine Research Institute, and countless other individuals in many countries around the Caribbean. Assistance during manuscript preparation was kindly given by Rogelio Diaz Fernandez, Cynthia Lagueux and Jim Wood. We are grateful for the constructive comments of Charles Caillouet, Matthew Godfrey, Michael Coyne, and two anonymous referees on an earlier draft. This work was supported by grants from FCO Environment Fund for the Overseas Territories, Department of Environment, Food and Rural Affairs and a NERC Fellowship (BG).

\section{References}

Aiken, J.J., Godley, B.J., Broderick, A.C., Austin, T.J., EbanksPetrie, G. \& Hays, G.C. (2001) Two hundred years after a commercial marine turtle fishery: the current status of marine turtles nesting in the Cayman Islands. Oryx, 352, 145-151.
Balazs, G.H., Nakai, G.L., Hau, S., Grady, M.J. \& Gilmartin, W.G. (in press) Year 2000 nesting of a captive-reared Hawaiian green turtle tagged and released as a yearling. In Proceedings of the 21st Symposium on Sea Turtle Biology and Conservation, Philadelphia, Pennsylvania. NOAA Technical Memorandum, NMFS-SEFSC.

Bell, C. \& Austin, T.J. (2002) The continued assessment of the reproductive status of the marine turtle rookery in the Cayman Islands. In Proceedings of the 22nd Annual Symposium on Sea Turtle Biology and Conservation (compiler J.A. Seminoff), p. 308. NOAA Technical Memorandum, NMFS-SEFSC-503.

Bjorndal, K.A. \& Bolten, A.B. (1988) Growth rates of immature green turtles, Chelonia mydas, on feeding grounds in the Southern Bahamas. Copeia, 3, 555-564.

Bjorndal, K.A., Bolten, A.B. \& Chaloupka, M.Y. (2000) Green turtle somatic growth model: evidence for density dependence. Ecological Applications, 10, 269-282.

Bjorndal, K.A., Bolten, B.A., Arenas, A., Zurita, J., D'Amino, A., Calderon, C., Parsons, J. \& Seminoff, J.A. (2003) Green turtle with living tag captured in the Southern Bahamas. Marine Turtle Newsletter, 101, 26.

Bolten, A.B. (2002) Variation in sea turtle life history patterns: neritic vs oceanic. In The Biology of Sea Turtles 2 (eds P.L. Lutz, J.A. Musick \& J. Wyneken), pp. 243-257. CRC Press, Boca Raton, USA.

Bolten, A.B., Martins, H.R., Natali, M.L., Thome, J.C. \& Marcovaldi, M.A. (1990) Loggerhead released in Brazil recaptured in Azores. Marine Turtle Newsletter, 48, 24-25.

Boulon, R.H. Jr \& Frazer, N.B. (1990) Growth of wild juvenile Caribbean green turtle (Chelonia mydas). Journal of Herpetology, 24, 441-445.

Bowen, B.W., Conant, T.A. \& Hopkins-Murphy, S.R. (1994) Where are they now? The Kemp's ridley headstart project. Conservation Biology, 83, 853-856.

Bresette, M. \& Gorham, J. (2001) Growth rates of juvenile green turtles Chelonia mydas from the Atlantic Coastal Waters of St. Lucie County, Florida, USA. Marine Turtle Newsletter, 91, 5-6.

Byles, R. (2001) Head-start experiment no longer rearing Kemp's ridleys. Marine Turtle Newsletter, 63, 1-3.

Caillouet, C.W. Jr (1998) Testing hypotheses of the Kemp's ridley head start experiment. Marine Turtle Newsletter, 79, 16-18.

Caillouet, C.W. Jr (2000) Sea turtle culture: Kemp's ridley and loggerhead turtle. In Encyclopaedia of Aquaculture (ed. R.R. Stickney), pp. 768-798. John Wiley, New York, USA.

Caillouet, C.W. Jr, Fontaine, C.T. \& Flanagan, J. P. (1993) Captive rearing of sea turtles: head starting Kemp's ridley, Lepidochelys kempii. In Proceedings of the American Association of Zoo Veterinarians (ed. R.E. Junge), pp. 8-12. SEFSC, Saint Louis, USA.

Caillouet, C.W. Jr, Fontaine, C.T., Williams, T.D. \& Klima, E.F. (1992) Accomplishments in Kemp's ridley head start experiment. In Proceedings of the 12th Annual Workshop on Sea Turtle Biology and Conservation (compilers J.I. Richardson \& T.H. Richardson), pp. 14-17. NOAA Technical Memorandum, NMFS-SEFC-361.

Carr, A. (1987) New perspectives in the Pelagic stage of sea turtle development. Conservation Biology, 12, 103-121.

Cayman Turtle Farm (2000) Application to register a captive breeding operation involving Chelonia mydas on Grand Cayman, Cayman Islands. Submitted by the CITES Management Authority of the United Kingdom of Great Britain and Northern Ireland pursuant to Resolution Conference 11.14.

Chaloupka, M.Y. \& Musick, J.A. (1997) Age, growth and population dynamics. In The Biology of Sea Turtles (eds P.L. 
Lutz \& J.A. Musick), pp. 223-276. CRC Press, Boca Raton, USA.

Coats, D.A. (1992) The loop current. In Physical Oceanography of the US Atlantic and Eastern Gulf of Mexico (eds J.D. Milliman \& E. Imamura). US Department of the Interior, Mineral Management Service, Atlantic OCS Region, Herndon, USA.

Collazo, J.A., Boulon, R. Jr \& Tallevast, T.L. (1992) Abundance and growth patterns of Chelonia mydas in Culebra, Puerto Rico. Journal of Herpetology, 26, 293-300.

Critchley, K.H., Wood, J.R. \& Wood, F.E. (1983) An alternative method to sand-packed incubation of sea turtle eggs. Herpetological Review, 14, 42.

Diez, C.E. \& Van Dam, R.P. (2002) Habitat effect on hawksbill turtle growth rates on feeding grounds at Mona and Monito Islands, Puerto Rico. Unpublished manuscript prepared for CITES Range State Regional Dialogue meeting, May 2002, Grand Cayman, British West Indies.

Dodd, C.K.J. \& Seigel, R.A. (1991) Relocation, repatriation, and translocation of amphibians and reptiles: are they conservation strategies that work? Herpetologica, 47, 336-350.

Donnelly, M. (1994) Sea Turtle Mariculture: A Review of Relevant Information for Conservation and Commerce. The Centre for Marine Conservation, Washington, DC, USA.

Dutton, P.H., Bowen, B.W., Owens, D.W., Barragan, A. \& Davis, S.K. (1999) Global phylogeography of the leatherback turtle (Dermochelys coriacea). Journal of Zoology, 248, 397-409.

Eckert, K.L. (1995) Anthropogenic threats to sea turtles. In Biology and Conservation of Sea Turtles (ed. K. Bjorndal), pp. 615. Smithsonian Institution Press, Washington, DC, USA.

Eckert, S.A., Crouse, D., Crowder, L.B., Maceina, M. \& Shah, A. (1994) Review of the Kemp's Ridley Sea Turtle Headstart Program. US Department Commerce, NOAA Technical Memorandum, NMFS-OPR-3.

Eliazar, P.J., Bjorndal, K.A. \& Bolten, A.B. (1996) Operation green turtle revisited. In Proceedings of the 16th International Symposium on Sea Turtle Biology and Conservation (compilers R. Byles \& Y. Fernandez), p. 158. NMFS-SEFSC-412.

Fontaine, C.T., Duronslet, M.J., Revera, D.B., Williams, T.D., Williams, J.A., Manzella, S.A., Stabenau, E.K., Landry, A.M. Jr \& Caillouet, C.W. Jr (1990) Kemp's Ridley Headstart Experiment and Other Sea Turtle Research at the Galveston Laboratory. Annual Report fiscal year 1989. NOAA Technical Memorandum, NMFS-SEFC-266.

Frazer, N.B. (1992) Sea turtle conservation and halfway technology. Conservation Biology, 6, 179-183.

Frazer, N.B. \& Ehrhart, L.M. (1985) Preliminary growth models for green, Chelonia mydas, and loggerhead, Carretta carretta, turtles in the wild. Copeia, 1, 73-79.

Gavilan, F.M. (2000) Impact of regulatory measures on Cuban marine turtle fisheries. In Proceedings of the 18th International Symposium on Sea Turtle Biology and Conservation (compilers A.F. Abreu-Grobois, R. Briseno, R. Marquez, F. Silve \& L. Sarti), pp.108-109. NMFS-SEFSC-436.

Godley, B.J., Lima, E.H.S.M., Åkesson, S., Broderick, A.C., Glen, F., Godfrey, M.H., Luschi, P. \& Hays, G.C. (2003) Movement patterns of green turtles in Brazilian coastal waters described by satellite tracking and flipper tagging. Marine Ecological Progress Series, 253, 279-288.

Hendrickson, L.P. \& Hendrickson, J.R. (1981) A new method for marking sea turtles? Marine Turtle Newsletter, 19, 6-7.

Heppell, S.S. \& Crowder, L.H. (1998) Prognostic evaluation of enhancement programs using population models and life history analysis. Bulletin of Marine Science, 622, 495-507.

Huff, J.A. (1989) Florida terminates headstart program. Marine Turtle Newsletter, 46, 1-2.
HYCOM Consortium (2004) HYCOM Consortium for Data Assimilative Modeling: Ocean Surface Currents. Http:/ / oceancurrents.rsmas.miami.edu/ [accessed 1 December 2004].

IUCN (2004) 2004 IUCN Red List of Threatened Species. IUCN, Gland, Switzerland [http:/ / www.redlist.org, accessed 23 November 2004].

Jacobson, E.R. (1993) Implications of infectious diseases for captive propagation and introduced programs of threatened/endangered reptiles. Journal of Zoological and Wildlife Medicine, 24, 245-255.

Jacobson, E.R. (1996) Guest editorial: marine turtle farming and health issues. Marine Turtle Newsletter, 72, 13-15.

Karl, S.A., Bowen, B.W. \& Avise, J.C., (1995) Hybridisation among the ancient mariners: characterisation of marine turtle hybrids with molecular genetic essays. Journal of Heredity, 86, 262-268.

King, W.F. (1995) Historical review of the decline of the green turtle and the hawksbill turtle. In Biology and Conservation of Sea Turtles (ed. K.A. Bjorndal), pp. 183-189. Smithsonian Institution Press, Washington, DC, USA.

Klima, E.F. \& McVey, J.P. (1995) Headstarting the Kemp's ridley turtle. In Biology and Conservation of Sea Turtles (ed. K.A. Bjorndal). Smithsonian Institution Press, Washington, DC, USA.

Krueger, C.C. \& May, B. (1991) Ecological and genetic effects of salmonid introductions in North America. Canadian Journal of Fisheries and Aquatic Science, 48 Suppl.1, 66-77.

Lagueux, C.J. (1998) Marine turtle fishery of Caribbean Nicaragua: human use patterns and harvest trends. PhD thesis, University of Florida, Gainsville, USA.

Lahanas, P.N., Bjorndal, K.A., Bolten, A.B., Encalada, S.E., Miyamoto, M.M., Valverde, R.A. \& Bowen, B.W. (1998) Genetic composition of a green turtle (Chelonia mydas) feeding ground population: evidence for multiple origins. Marine Biology, 130, 345-352.

Lewis, B. (1940) The Cayman Islands and the marine turtle. Bulletin of the Institute of Jamaica Science Series, 2, 56-65.

Luke, K., Horrocks, J.A. \& LeRoux, R.A. (2004) Origins of green turtle (Chelonia mydas) feeding aggregations around Barbados, West Indies. Marine Biology, 144, 799-805.

Mendonca, M.T. (1981) Comparative growth rates of wild immature Chelonia mydas and Caretta caretta in Florida. Journal of Herpetology, 15, 447-451.

Meylan, A. (1995) Sea turtle migration - evidence from tag returns. In Biology and Conservation of Sea Turtles (ed. K.A. Bjorndal), pp. 91-103. Smithsonian Institution Press, Washington, DC, USA.

Mortimer, J.A. (1995) Headstarting as a management tool. In Biology and Conservation of Sea Turtles (ed. K.A. Bjorndal), pp. 613-615. Smithsonian Institution Press, Washington, DC, USA.

Mrosovsky, N. (1983) Conserving Sea Turtles. British Herpetological Society, London, UK.

Mrosovsky, N. (in press) Translocating turtles: trials, tribulations and triumphs. Informes Technicos del Instituto Canario de Ciencias Marinas. In Proceedings of a Conference 2 $\& 3$ December 2002, at Pajara, Fuerteventura, Canary Islands. First Micronesian Sea Turtle Workshop and Modern Applicable Technologies (ed. L.F. Lopez).

Mrosovsky, N. \& Godfrey, M.H. (2003) Living tag, living reputation. Marine Turtle Newsletter, 99, 3-4.

National Research Council (1990) Decline of the Sea Turtles: Causes and Prevention. National Academy Press, Washington, DC, USA. 
Rhymer, J.M. \& Simberloff, D. (1996) Extinction by hybridisation and introgression. Annual Review of Ecology and Systematics, 27, 83-109.

Shaver, D.J. \& Caillouet, C.W. Jr (1998) More Kemp's ridley turtles return to south Texas to nest. Marine Turtle Newsletter, 82, 1-5. [Erratum published in 1999, Marine Turtle Newsletter, $83,28]$

Wibbels, T., Frazer, N., Grassman, J., Hendrickson, J. \& Pritchard, P. (1989) Blue Ribbon Panel Review of the National Marine Fisheries Service Kemp's Ridley Headstart Program. A report to the National Marine Fisheries Service, USA, submitted to the Southeast Regional Office, August 1989.

Williams, P. (1993) NMFS to concentrate on measuring survivorship, fecundity of head-started Kemp's ridleys in the wild. Marine Turtle Newsletter, 63, 3-4.

Wood, F. (1991) Turtle culture. In Production of Aquatic Animals (ed. C.E. Nash), pp. 225-234. Elsevier Science Publishers, Amsterdam, The Netherlands.

Wood, F.E. \& Wood, J.R. (1985) Release of "living tag" marked green turtles in the Cayman Islands. Marine Turtle Newsletter, $32,5-6$.

Wood, J.R. (1982) Release of captive-bred green sea turtles by Cayman Turtle Farm Ltd. Marine Turtle Newsletter, 20, 6-7.

Wood, J.R. \& Wood, F.E. (1979) Artificial incubation of green sea turtle eggs (Chelonia mydas). Proceedings of the World Mariculture Society, 10, 216-221.

Wood, J.R. \& Wood, F.E. (1993) Release and recapture of captive-reared green sea turtles Chelonia mydas, in the waters surrounding the Cayman Islands. Herpetological Journal, 3 , 84-89.
Woody, J.B. (1981) Head starting of Kemp's ridley. Marine Turtle Newsletter, 63, 3-4.

Woody, J.B. (1990) Guest editorial: is headstarting a reasonable conservation measure? On the surface, yes; in reality, no. Marine Turtle Newsletter, 50, 8-11.

Woody, J.B. (1991) Guest editorial: it's time to stop headstarting Kemp's ridley. Marine Turtle Newsletter, 55, 7-8.

Zug, G.R. \& Glor, R.E. (1998) Estimates of age and growth in a population of green sea turtles (Chelonia mydas) from the Indian River lagoon system, Florida: a skeletochronological analysis. Canadian Journal of Zoology, 76, 1497-1506.

\section{Biographical sketches}

Catherine Bell works at the Cayman Islands Department of Environment and with the Marine Turtle Research Group at the Centre for Ecology and Conservation, University of Exeter in Cornwall, UK. The Cayman Islands Department of Environment undertakes monitoring, conservation and research related to all aspects of the ecosystems in the Cayman Islands. Cayman Turtle Farm is a crown corporation of the Cayman Islands that raises the green turtle in captivity to supply products to the local commercial market and provides facilities for release, research and education. The Marine Turtle Research Group is active in both fundamental and applied research related to marine turtles in the UK and internationally. 